\title{
IMPLEMENTASI LESSON STUDY PADA METODE AKTIF TIPE QUIS TEAM TERHADAP PENGEMBANGAN KARAKTER MAHASISWA MATA KULIAH AKUNTANSI II UNIVERSITAS MUAHAMMADIYAH METRO TAHUN AJARAN 2015/2016
}

\author{
Wakijo $^{1)}$ Maryatun $^{2)}$ \\ Pendidikan Ekonomi FKIP Universitas Muhammadiyah Metro \\ Wakijo12umm@yahoo.com
}

\begin{abstract}
Abstrak
Keterlambatan saat perkuliahan, pengumpulan tugas bahkan saat Quis dan ketidakjujuran dalam mengerjakan Quis sering dilakukan oleh mahasiswa, ketidakjujuran dengan menggunakan tehnologi juga ditemukan, misalnya memotret hasil ujian yang kemudian dikirimkan kepada teman lain. Oleh karena itu perlu dilakukan penelitian yang bertujuan untuk mengembangkan karakter jujur, disiplin, bersahabat, mandiri dan kerja keras.

Penelitian ini menggunakan penelitian tindakan kelas (PTK) dengan mengimplementasikan lesson study dengan Metode Aktif Tipe Quis Team, yang dilaksnakan dengan 2 siklus dan melalui 4 tahapan yaitu perencanaan, pelaksanaan, pengamatan dan refleksi. Subyek penelitian adalah mahasiswa Pendidikan Ekonomi semester IV Tahun Akademik 2014/2015. Data penelitian diperoleh dari lembar observasi, dokumentasi photo. Data penelitian ini di ambil dari proses pelaksanaan perkuliahan. Hasil penelitian menunjukkan bahwa karakter jujur, disiplin, bersahabat, mandiri dan kerja keras. Karakter jujur ditandai dengan jumlah mahasiswa yang mengemukakan pendapat sesuai dengan yang diyakininya sebesar76,45,Tidak mencontek dalam mengerjakan tugas sebesar 75,7\%, menyelesaikan tugas sesuai dengan aturan yang diberikan pada siklus I sebesar $72,9 \%$ dan meningkat pada siklus II menjadi $83,1 \%, 77,0 \%, 75,7 \%$; dan mahasiswa yang berkarakter disiplin: Tertib dalam mengerjakan tugas sebesar 75\%; mentaati aturan berbicara yang ditentukan dalam sebuah diskusi kelas sebesar 75\%; meningkat pada siklus II sebesar 76,4\% dan 77,0\%. Mahasiswa yang berkarakter bersahabat: bekerjasama dalam tim 77\%; Memberikan pendapat dalam kerja tim 74,3\% meningkat pada siklus II menjadi 77,7\% dan 75,7\%; mahasiswa yang berkarakter mandiri: Menyelesaikan sendiri tugas yang menjadi tanggung jawabnya dengan skor $73,6 \%$ pada siklus II meningkat menjadi 75,7\%. Mahasiswa yang berkarakter kerja keras: Tidak putus asa dalam menghadapi kesulitan belajar dengan skor $72,3 \%$, Berusaha untuk mencari informasi tentang materi dari berbagai sumber skor $83,8 \%$; Menggunakan waktu secara efektif untuk menyelesaikan tugas-tugas dengan skor $73,6 \%$ pada siklus II naik menjadi $75,7 \% ; 85,1 \%$ dan $77,7 \%$
\end{abstract}

Kata Kunci : Lesson Study, Metode Aktif Tipe Quis Team, Karakter

\section{PENDAHULUAN}

Nilai karakter mulia jujur, disiplin, bersahabat, mandiri dan kerja keras mulai berkurang pada diri mahasiswa program studi pendidikan ekonomi FKIP UM Metro. Menurunnya nilai karakter antara lain: ketidak jujuran dalam mengerjakan tugas, tidak mengumpulkan tugas tepat 
waktu, mengobrol sendiri ketika

pembelajaran, dimana dalam perkuliahan berlangsung, tidak pelaksanaannya meliputi pengkajian memberikan pendapat ketika kerja kelompok, tidak menyelesaikan tugas yang menjadi tanggungjawabnya, tidak mau mencari informasi tentang materi yang dibahas. Beberapa tugas yang dikumpulkan memiliki jawaban yang sama persis mulai dari awal, bahkan kesalahan yang terjadi juga sama. Karakter atau nilainilai yang mulia ini merupakan salah satu hal yang diperoleh melalui pendidikan atau pembelajaran.

Menurunnya nilai karakter tersebut di atas yang terus berkembang menuju ke arah yang kurang baik, maka perlu kiranya pendidikan karakter mulai diintegrasikan ke dalam perkuliahan Akuntansi II. Hal ini juga sejalan dengan UU Nomor 20 Tahun 2003 tentang Sistem Pendidikan nasional pasal 3 menyatakan bahwa Pendidikan nasional berfungsi mengembangkan kemampuan dan membentuk watak serta peradaban bangsa yang bermartabat dalam rangka mencerdaskan kehidupan bangsa.

Penerapan perkuliahan dengan mengimplementasikan lesson study dengan Metode Aktif Tipe Quis Team yang didukung dengan system, perangkat dan metode merupakan salah satu cara yang tepat untuk pengembangan karakter jujur, disiplin,bersahabat, mandiri dan kerja keras . Lesson study merupakan bentuk upaya untuk meningkatkan hasil

terhadap proses pembelajaraan melalui penelitian untuk mengkaji keunggulan dan kelemahan pembelajaran yang dilaksanakan di kelas. Lesson Study dalam pelaksananaannya melalui 3 hal yaitu:

1. Plan (perencanaan)

2. Do (pelaksanaan)

3. See (refleksi)

Penerapan lesson study dalam proses pembelajaran dimulai dari merencanakan pembelajaran berdasarkan tujuan pembelajaran secara kolaburatif, mengobservasi pembelajaran yang bertujuan untuk mengumpulkan data pelaksanaan pembelajaran, menggunakan data hasil observasi untuk melakukan refleksi pembelajaran secara luas dan mendalam, berdasarkan hasil refleksi tersebut disusunlah pembelajaran berikutnya.

Metode Aktif Tipe Quis Team Merupakan salah satu tipe pembelajaran yang mampu meningkatkan keaktifan mahasiswa dalam proses belajar". Metode pembelajaran aktif tipe Quiz Team ini diawali dengan menerangkan materi perkuliahan secara klasikal, lalu mahasiswa dibagi ke dalam kelompok besar. Semua anggota kelompok bersamasama mempelajari materi tersebut melalui lembar kerja. Mereka mendiskusikan materi tersebut, saling memberi arahan, 
saling memberikan pertanyaan dan jawaban untuk memahami materi tersebut. Setelah selesai materinya maka diadakan suatu pertandingan akademis, sehingga mahasiswa termotivasi untuk belajar.

Langkah-langkah metode pembelajaran aktif tipe Quiz Team adalah sebagai berikut:

1. Langkah pertama dosen memilih topik yang biasa disajikan dalam tiga segmen. Kemudian dosen menjelaskan skenario pembelajaran. Setelah selesai dosen menyajikan materi perkuliahan.

2. Mahasiswa dibagi ke dalam tiga kelompok besar ( Tim A, Tim B dan Tim C).

3. Dosen meminta tim A untuk menyiapkan kuis jawaban singkat, sementara tim B, dan tim C menggunakan waktu untuk memeriksa catatan mereka.

4. Tim A memberikan kuis kepada tim B, jika tim B tidak dapat menjawab pertanyaan, tim C segera menjawabnya.

5. Tim A mengarahkan pertanyaan berikutnya kepada anggota tim C, dan mengulang proses tersebut.

6. Ketika kuisnya selesai, lanjutkan segmen ke dua dari perkuliahan dan minta tim B sebagai pemandu kuis.

7. Setelah tim B menyelesaikan kuisnya, lanjutkan dengan segmen ke tiga dari pelajaran dan tunjuklah tim $\mathrm{C}$ sebagai pemandu kuis.

Berdasarkan uraian di atas maka penelitian yang berjudul “ Implementasi Lesson Study Pada Metode Aktif Tipe Quis Team Terhadap Pengembangan Karakter Mahasiswa Mata Kuliah Akuntansi II "dilaksanakan untuk mengetahui perkembangan karakter mahasiswa.

Berdasarkan latar belakang permasalahan yang diuraikan di atas maka penelitian ini memiliki rumusan masalah bagaimana mengimplementasikan lesson study dengan Metode Aktif Tipe Quis Team terhadap pengembangan karakter mahasiswa?

Sesuai dengan rumusan maslah di atas maka peneliti memiliki tujuan : untuk mendiskripsikan pengimplementasian lesson study dengan Metode Pembelajaran Aktif Tipe Quis Team terhadap pengembangan karakter mahasiswa.

Oleh karena itu diharapkan penelitian ini dapat dimanfaatkan (1) untuk menyusun sebuah perangkat dan metode perkuliahan bagi setiap mata kuliah Program Studi Pendidikan Ekonomi untuk menghasilkan guru-guru pendidikan ekonomi yang memiliki karakter yang unggul, (2) memberikan bukti sebagai pendorong penelitian-penelitian tentang pengembangan karakter secara terintegrasi 
dalam system perkuliahan untuk membantu mengatasi problematika kenakalan remaja, (3) bahan pemikiran untuk menyusun kurikulum yang mengintegrasikan pendidikan karakter.

\section{METODE PENELITIAN}

Metode yang digunakan yaitu menggabungkan antara tahapan pada Penelitian Tindakan Kelas (PTK) dengan Lesson Study (LS) dan Metode Aktif Tipe Quis Team merupakan usaha untuk memperbaiki proses penyelenggaraan perkuliahan Akuntansi II dalam rangka pengembangan karakter mahasiswa. Tindakan dalam penelitian ini dengan mengimplementasikan lesson study dengan Metode Pembelajaran Aktif Tipe Quis Team terhadap pengembangan karakter mahasiswa. Dalam Penelitian Tindakan Kelas, kehadiran peneliti mutlak diperlukan karena pengumpulan data dilakukan dalam situasi sesungguhnya oleh anggota tim peneliti.

Sebagai subjek penelitian adalah mahasiswa Program Studi Pendidikan Ekonomi FKIP Universitas Muhammadiyah Metro yang menempuh mata kuliah Akuntansi II semester genap tahun akademik 2014/2015. Jumlah mahasiswa dalam kelas ini adalah 37 orang yang terdiri 13 orang laki-laki dan 24 orang perempuan. Penelitian ini melibatkan satu dosen sebagai pengampu mata kuliah dan sekaligus sebagai peneliti, dan satu dosen sebagai anggota peneliti sekaligus sebagai kolaboratur dan observer. PTK ini dilaksanakan dalam dua siklus dengan 3 tahap kegiatan pada setiap siklusnya yaitu Plan, Do, dan See.

Penelitian ini merupakan penggabungan Penelitian Tindakan Kelas dan Lesson Study, dimana dalam pelaksanaan pembelajaran terdapat beberapa tahapan dalam satu siklus yaitu:

1. Tahap Penelitian

a. Pendahuluan

1. Menyusun jadwal penelitian

2. Menentukan subyek penelitian

3. Mencari data awal (pre test) untuk menentukan anggota kelompok

b. Tahap Tindakan

1. Siklus I

a) Plan (Perencanaan)

Aktivitas yang dilakukan pada tahap plan adalah secara kolaboratif dosen model dengan observer menyusun rencana pelaksanaan pembelajaran (RPP), menyiapkan lembar kegiatan mahasiswa (LKM) menyiapkan lembar observasi (pengamatan).

b) Do

Tahap ini dosen model menerapkan rencana 
pelaksanaan pembelajaran yang telah direncanakan yakni dalam setiap perkuliahan selama 2 x 50 menit dilakukan kegiatan sebagai berikut:

1) Apersepsi tentang pemahaman konsep-konsep yang telah dibicarakan dengan indikator , kompetensi dan tujuan yang harus dikuasai.

2) Penyajian materi secara garis besar oleh dosen model

3) Pembagian mahasiswa ke dalam tiga kelompok besar dengan tingkat kemampuan akademik yang heterogen ( baik kemampuan akademik, jenis kelamin).

4) Pemberian lembar kerja mahasiswa berisi permasalahan yang harus diselesaikan oleh setiap kelompok.

5) Mahasiswa berdiskusi dengan teman kelompoknya, dan dosen model mendampingi selama berdiskusi kelompok menyelesaian lembar soal.

6) Selesai mengerjakan tugas secara kelompok, mahasiswa melakukan unjuk kerja ke depan kelas mempresentasikan permasalahan yang diberikan dosen. Dalam unjuk kerja dosen model sebagai moderator dan sekaligus sebagai nara sumber.

7) Dosen bersama mahasiswa menarik kesimpulan dari permasalahan yang dibahas.

c) See

Tahap pengamatan dan refleksi (see) bertujuan untuk menemukan kelebihan dan kekurangan pelaksanaan proses pembelajaran. Dalam tahap ini dilakukan diskusi secara formal yang dipimpin oleh seorang moderator dan notulis. Dosen model diberi kesempatan pertama kali untuk melakukan refleksi diri tentang: perasaan dosen model, sebelum, saat dan setelah melaksanakan proses pembelajaran, alur perencanaan pembelajaran yang berhasil dari yang belum dilaksanakan. Kemudian dosen model mendengarkan hasil temuan dosen observer yang mengikuti pengamatan pembelajaran berlangsung berdasarkan data yang ditemukan.

Implementasi atau pelaksanaan tindakan siklus I terdiri dari 2 pertemuan 
untuk melaksanakan system perkuliahan , perangkat dan metode perkuliahan.

Observasi dilakukan oleh peneliti dengan melakukan pengamatan secara sistematis dan obyektif terhadap kegiatan perkuliahan dengan instrument lembar pengamatan.

Setelah data diperoleh dan didiskuisikan dilakukan refleksi dengan membahas kekurangan dan hambatan beserta cara mengatasinya sebagai bahan penyusunan siklus II . Pada siklus II dilakukan tahap yang sama terdiri dari 2 pertemuan dan diakhiri dengan membandingkan hasil analisis dan refleksi untuk mendapatkan hasil penelitian.

Instrumen pengamatan proses perkuliahan digunakan untuk mendapatkan data pelaksanaan proses pembelajaran dengan mengamati keterlaksanaan proses pembelajaran bagi mahasiswa. Instrumen pengembangan karakter digunakan untuk mendapatkan data munculnya karakter Jujur, disiplisn, bersahabat, mandiri, dan kerja keras. Data pengamatan karakter membawa lembar observasi, karakter jujur diperoleh dengan menghitung jumlah mahasiswa yang mengerjakan quis tidak mencontek, menyelesaikan quis sesuai dengan aturan yang berikan. Karakter disiplin dan seterusnya juga disediakan ruang untuk membubuhkan catatan temuan di lapangan baik yang positif maupun yang negative. Lembar soal quis digunakan untuk menilai hasil belajar kognitif mahasiswa dengan mencatat jumlah mahasiswa yang menjawab benar.

Data yang terkumpul dari instrumen diproses dalam beberapa tahap, antara lain reduksi data, penyajian data, evaluasi dan penarikan kesimpulan. Dalam proses perkuliahan, pengembangan karakter dan hasil penelitian untuk medapatkan skor pada setiap indikator sehingga dapat teramati bagaimana peningkatannya pada setiap siklus.

Data keterlaksanaan proses perkuliahan diolah dengan teknik persentase yang kemudian didiskripsikan.

\section{PEMBAHASAN HASIL PENELITIAN}

Proses perkuliahan diawali dengan penjelasan indicator yang akan dicapai dengan menggunakan slide power point. Sebelum masuk ke materi inti, dosen mengajukan pertanyaan reviu yang harus dijelaskan oleh mahasiswa. Setelah itu mahasiswa mengerjakan soal secara tim untuk memantapkan materi sebelumnya. Untuk mengantarkan mahasiswa pada materi yang akan dipelajari, dosen mengajukan permasalahan yang harus diselesaikan mahasiswa secara tim. Dalam kegiatan kerja tim, dosen mengunjungi setiap tim untuk membantu menyelesaikan permasalahan. Kemudian dosen meminta mahasiswa untuk presentasi materi yang didiskusikan dan member kesempatan tim 
mahasiswa lain untuk bertanya. Dosen memberi penguatan dan penjelasan konsep melalui kegiatan dialog interatif dengan menggunakan slide power point. Perkuliahan diakhiri dengan memberikan quis membahas permasalahan yang ada di lembar kerja mahasiswa. Setiap pengerjaan quis dosen memberikan waktu penyelesaian yang disepakati dengan mahasiswa. Dalam pengerjaan quis dosen mengingatkan system perkuliahan yang disepakati mengenai kejujuran kepada mahasiswa.

Hasil pelaksanaan proses perkuliahan dengan penerapan Metode Pembelajaran Aktif Tipe Quis Team pada siklus I terlaksana dengan baik. Namun terdapat bagian keterlibatan mahasiswa dalam mengerjakan quis masih cenderung bersifat kelompok atau klasikal. Selain itu dosen belum merata dalam membantu pelaksanaan kerja tim. Dalam kegiatan kerja tim terdapat mahasiswa yang tidak mengikuti aturan-aturan yang telah ditentukan. Tahap persentasi hanya dimonopoli oleh mahasiswa tertentu. Pada saat pengerjaan quis terdapat kesalahan pada lembar soal quis.

Untuk memperbaiki kekurangan kekurangan tersebut, maka refleksi siklus I memberikan rekomendasi sebagai berikut: (1) perlu usaha untuk mendorong mahasiswa berani mengerjakan soal secara individu tidak secara kelompok, (2) dosen dapat menjelaskan permasalahan yang sama pada kerja tim, (3) memberikan kesempatan pada mahasiswa lain untuk menyampaikan komentar (pendapat, ide lain), (4) lembar quis perlu dipersiapkan secara teliti.

Dengan usaha-usaha, hasil refleksi siklus I maka rata-rata persentase ketercapaian indikator karakter mahasiswa proses perkuliahan hasilnya seperti tabel di bawah ini:

Tabel 1. Hasil Evaluasi Proses Pembelajaran Siklus I

\begin{tabular}{|c|c|c|c|c|}
\hline No & Indikator & Aspek yang diamati & $\%$ & Rata-Rata \\
\hline \multirow{3}{*}{1.} & \multirow{3}{*}{ Jujur } & $\begin{array}{l}\text { a. Mengemukakan pendapat sesuai dengan yang } \\
\text { diyakininya. }\end{array}$ & 76,4 & \multirow{3}{*}{75} \\
\hline & & b. Tidak mencontek dalam mengerjakan tugas. & 75,7 & \\
\hline & & $\begin{array}{l}\text { c. Menyelesaikan tugas sesuai dengan aturan } \\
\text { yang diberikan }\end{array}$ & 72,9 & \\
\hline \multirow[b]{2}{*}{2.} & \multirow[b]{2}{*}{ Disiplin } & a. Tertib dalam mengerjakan tugas & 75 & \multirow[b]{2}{*}{75} \\
\hline & & $\begin{array}{l}\text { b. Mentaati aturan berbicara yang ditentukan } \\
\text { dalam sebuah diskusi kelas }\end{array}$ & 75 & \\
\hline 3. & Bersahabat & a. Bekerjasama dalam tim & 77 & \\
\hline
\end{tabular}




\begin{tabular}{|c|c|c|c|c|}
\hline & & b. Memberikan pendapat dalam kerja tim & 74,3 & 75,7 \\
\hline 4. & Mandiri & $\begin{array}{l}\text { Menyelesaikan sendiri tugas yang menjadi } \\
\text { tanggung jawabnya }\end{array}$ & 73,6 & 73,6 \\
\hline \multirow{3}{*}{5.} & \multirow{3}{*}{$\begin{array}{l}\text { Kerja } \\
\text { keras }\end{array}$} & $\begin{array}{l}\text { a. Tidak putus asa dalam menghadapi kesulitan } \\
\text { belajar }\end{array}$ & 72,3 & \multirow{3}{*}{76,6} \\
\hline & & $\begin{array}{l}\text { b. Berusaha untuk mencari informasi tentang } \\
\text { materi dari berbagai sumber }\end{array}$ & 83,8 & \\
\hline & & $\begin{array}{l}\text { c. Menggunakan waktu secara efektif untuk } \\
\text { menyelesaikan tugas-tugas }\end{array}$ & 73,6 & \\
\hline
\end{tabular}

Dari hasil evaluasi proses pembelajaran terlihat hasil tindakan siklus I dari alat pengumpul data lembar observasi dan dokumentasi foto didapatkan hasil bahwa karakter mahasiswa dari 11 indikator karakter mahasiswa yang diamati sudah tercapai 6 indikator karakter, dan 5 indikator karakter belum tercapai. Indikator karakter yang tercapai antara lain: Mengemukakan pendapat sesuai dengan yang diyakininya, Tidak mencontek dalam mengerjakan tugas, Tertib dalam mengerjakan tugas, Mentaati aturan berbicara yang ditentukan dalam sebuah diskusi kelas, Bekerjasama dengan tim, Berusaha untuk mencari informasi tentang materi dari berbagai sumber, sedangkan indikator karakter yang belum tercapai antara lain: Menyelesaikan tugas sesuai dengan aturan yang diberikan, memberikan pendapat dalam kerja tim, menyelesaikan sendiri tugas yang menjadi tanggungjawabnya, tidak putus asa dalam menghadapi kesulitan dalam belajar, menggunakan waktu secara efektif untuk menyelesaikan tugas-tugas. Karakter tertinggi mahasiswa di siklus I mencapai $83,8 \%$ berkatagori sudah tercapai. Hasil dokumentasi foto saat diskusi kelompok Tim terlihat masih ada beberapa mahasiswa yang belum menyelesaikan tugas sesuai dengan aturan yang diberikan, ada kelompok Tim yang belum terlihat adanya memberikan pendapat dalam kerja Tim, ada yang bermalas-malasan, ngobrol, masih ada anggota tim yang belum menggunakan waktu secara efektif untuk menyelesaikan tugas.Membentuk 3 kelompok besar ternyata masih kurang efektif, karena banyak mahasiswa yang kurang bekerjasama dan masih mengandalkan temanya.

Siklus II dilaksanakan mengikuti masukan-masukan hasil refleksi siklus I sesuai dengan skala pengembangan karakter, nilai presentase tersebut masuk dalam kategori baru sebagian mahasiswa memunculkan indicator karakter jujur, disiplin bersahabat dan kerja keras, sedangkan indikator mandiri belum muncul. Karakter jujur ditandai dengan jumlah mahasiswa yang mengemukakan 
pendapat ketika kerja tim, tidak menyontek mengerjakan soal, menyelesaikan tugas sesuai dengan aturan skornya meningkat pada siklus II, karakter disiplin ditandai dengan mahasiswa menunjukkan sikap tertib dalam mengerjakan tugas dan mentaati aturan berbicara yang ditentukan sebuah diskusi kelas meningkat skornya pada siklus II. Perkembangan karakter bersahabat, mandiri dan kerja keras juga skornya mengalami peningkatan, hal ini terlihat dalam tabel berikut:

Tabel 2. Hasil Evaluasi Proses Pembelajaran Siklus II

\begin{tabular}{|c|c|c|c|c|}
\hline No & Indikator & Aspek yang diamati & $\%$ & Rata-Rata \\
\hline \multirow{3}{*}{1.} & \multirow{3}{*}{ Jujur } & $\begin{array}{l}\text { a. Mengemukakan pendapat sesuai } \\
\text { dengan yang diyakininya. }\end{array}$ & 83,1 & \multirow{3}{*}{78,6} \\
\hline & & $\begin{array}{l}\text { Tidak mencontek dalam mengerjakan } \\
\text { tugas. }\end{array}$ & 77,0 & \\
\hline & & $\begin{array}{l}\text { c. Menyelesaikan tugas sesuai dengan } \\
\text { aturan yang diberikan }\end{array}$ & 75,7 & \\
\hline \multirow{2}{*}{2.} & \multirow{2}{*}{ Disiplin } & a. Tertib dalam mengerjakan tugas & 76,4 & \multirow[b]{2}{*}{76,7} \\
\hline & & $\begin{array}{ll}\text { b. } & \text { Mentaati aturan berbicara yang } \\
& \text { ditentukan dalam sebuah diskusi kelas }\end{array}$ & 77,0 & \\
\hline \multirow{2}{*}{3.} & \multirow{2}{*}{ Bersahabat } & a. Bekerjasama dalam tim & 77,7 & \multirow[b]{2}{*}{76,7} \\
\hline & & b. Memberikan pendapat dalam kerja tim & 75,7 & \\
\hline 4. & Mandiri & $\begin{array}{l}\text { Menyelesaikan sendiri tugas yang menjadi } \\
\text { tanggung jawabnya }\end{array}$ & 75,7 & 75,7 \\
\hline \multirow{3}{*}{5.} & \multirow{3}{*}{ Kerja keras } & $\begin{array}{l}\text { a. Tidak putus asa dalam menghadapi } \\
\text { kesulitan belajar }\end{array}$ & 75,7 & \multirow{3}{*}{79,5} \\
\hline & & $\begin{array}{l}\text { b. Berusaha untuk mencari informasi } \\
\text { tentang materi dari berbagai sumber }\end{array}$ & 85,1 & \\
\hline & & $\begin{array}{l}\text { c. Menggunakan waktu secara efektif } \\
\text { untuk menyelesaikan tugas-tugas }\end{array}$ & 77,7 & \\
\hline
\end{tabular}

Perkuliahan pada siklus II dilaksanakan pada materi laporan keuangan, pada proses perkuliahan banyak mahasiswa yang mengalami kesulitan dalam memasukan transaksi keperkiraan yang ditentukan dalam lapaoran keuangan dengan bantuan neraca lajur. Kesulitan tersebut berdampak dalam proses diskusi tim sehingga setiap tim banyak yang meminta bantuan dosen. Hal ini memberikan dampak pada mahasiswa aktiv dan antusias bahkan tertantang dengan materi yang diberikan oleh dosen, walaupun ada anggota tim yang merasa belum mampu menyelesaikan permasalahan sehingga hanya diam saja di kelas. Berdasarkan hasil tindakan siklus II dari berbagai alat pengumpul data antara lain observasi, dokumen foto didapatkan hasil bahwa aktivitas belajar mahasiswa, 
dari 11 indikator karakter mahasiswa yang diamati sudah tercapai secara keseluruhan. Karakter mahasiswa di siklus II mencapai $85,1 \%$ sudah berkategori berkarakter karena sudah mencapai $\geq 75 \%$ dari jumlah mahasiswa.
Hasil evaluasi proses perkuliahan dengan metode belajar aktif tipe Quiz Team terhadap perkembangan nilai-nialai karakter pada perkuliahan Akuntansi II di siklus I dan Siklus II dapat dilihat pada Tabel 3 berikut:

Tabel 3. Hasil Evaluasi Proses Perkuliahan Siklus I dan Siklus II

\begin{tabular}{|l|l|c|c|}
\hline No. & \multicolumn{1}{|c|}{ Indikator } & $\begin{array}{c}\text { \% } \\
\text { Siklus I }\end{array}$ & $\begin{array}{c}\text { \% } \\
\text { Siklus II }\end{array}$ \\
\hline 1. & Jujur & 75 & 78,6 \\
\hline 2. & Disiplin & 75 & 76,7 \\
\hline 3. & Bersahabat & 75,7 & 76,7 \\
\hline $\mathbf{4}$ & Mandiri & 73,6 & 75,7 \\
\hline $\mathbf{5}$ & Kerja Keras & 76,6 & 79,5 \\
\hline
\end{tabular}

Berdasarkan tabel di atas tampak bahwa terdapat peningkatan yang baik pada indikator-indikator nilai karakter pada diri mahasiswa dengan menggunakan pendekatan metode belajar aktif tipe Quiz Team. Yaitu:

Indikator jujur siklus I 75\% naik di siklus II menjadi 78,6\%, Disiplin siklus I 75\% naik ke siklus II menjadi $76,7 \%$, Bersahabat siklus I 75,7\% naik di siklus II menjadi 76,7\%, Mandiri, siklus I 73,6\% naik di siklus II menjadi 75,7 \%, Kerja Keras siklus I $76,6 \%$ naik di siklus II menjadi $79,5 \%$.

\section{KESIMPULAN}

Simpulan yang dapat ditarik dari hasil penelitian ini adalah melalui Lesson Study dengan pendekatan metode belajar aktif tipe Quiz Team pada mata kuliah Akuntansi II dapat meningkatkan pengembangan nilai-nilai karakter mahasiswa. Hasil evaluasi siklus II menunjukkan peningkatan pada indikatorindikator yang diamati pada penelitian ini yang berkaitan dengan nilai-nilai karakter yang ada pada diri mahasiswa yakni Jujur, Disiplin, Bersahabat, dan Kerja Keras.

Berdasarkan hasil penelitian ini, maka disarankan penerapan Lesson Study dengan pendekatan metode belajar aktif tipe Quiz Team dapat diterapkan dalam perkuliahan-perkuliahan pada mata kuliah lainnya. 
ISSN: 2337-4721 Vol.3. NNo.2 (2015) 29-39

\section{DAFTAR PUSTAKA}

Aunillah, Nurla Isna. 2011. Panduan Menerapkan Pendidikan Karakter di Sekolah Yogjakarta: Laksana

Dalvi. 2006. Upaya Meningkatkan Keaktifan Belajar Mahasiswa dalam Pembelajaran Agama dengan Menggunakan Metode Belajar Aktif Tipe Quiz Team. Jurnal Dosen

Depdiknas (2009). Pedoman Penulisan Karya Ilmiah. Depdiknas UPI

Jamaludin.2011 Pentingnya Pendidikan Karakter di Sekolah Menengah Kejuruan. (Online).Tersedia :http://jamaludin 270790. blogspot.com/2011. makalah Pendidikan karakter siswa smk.html..

Prayitno dan Belferik Manulang.2010. Pendidikan Karakter dalam pembangunan Bangsa. Sumatra Utara: Penerbit Pascasarjana Universitas Negeri Medan
Ratna Megawangi 2004 Pendidikan KarakterKajian Teori dan Praktek di Sekolah. Bandung: PT Remaja Rosdakarya.

Undang - Undang RI Nomor 20. 2003. Tentang Sistem Pendidikan Nasional Pasal 3

Silberman, Melvin L. 2006, Active Learning 101 Cara belajar mahasiswa aktif. Bandung: Musamedia

Warsono. Dan Hariyanto, 2013. Pembelajaran Aktif. Bandung: PT Remaja Rosdakarya 